\title{
The Legalization of Abortion in the Discourse of the Newspapper Folha de São Paulo (2011-2014)
}

\author{
Thiago Mikael-Silva ${ }^{1}$ \\ Faculdade Ciências da Vida, Sete Lagoas, MG, Brazil \\ Alberto Mesaque Martins \\ Departamento de Psicologia da Universidade Federal de Minas Gerais, \\ Belo Horizonte, $M G$, Brazil
}

\begin{abstract}
This study is aimed to analyze the discourses about the legalization and decriminalization of abortion conveyed by Brazilian print media. On the basis of French perspective of discourse analysis, it was analyzed in the news, published between the periods of January 2011 to August 2014 in the newspapers, Folha de São Paulo. The results suggest that divulgation of the theme legalization of abortion has a relationship with shade in contexts of anger. In year 2011, after election campaign for the presidency, we observed attempts to silence this theme. The year 2012 was marked by the liberation of abortion in cases of anencephaly, contributing to the dislocation of the theme from the perspective of Public Health. This fact was strengthened in 2013 with the support of the Conselho Federal de Medicina (CFM). The first 6 months of 2014 was characterized as an escape taken by the major candidates during presidential elections. It identifies religious, sanitary, feminists, midiatic and electoralists discourses. This study should contribute to the debate about the legalization of abortion in Brazil, being necessary to reflect about the media tools and its capacity to legitimize a practice that cause controversy, but has acceptance when occurs silently and invisibly.
\end{abstract}

Keywords: Abortion, Discourse Analysis, mass media, Public Health.

\section{A Legalização do Abortamento no Discurso do Jornal Folha de São Paulo (2011-2014)}

\section{Resumo}

O estudo teve como objetivo analisar os discursos sobre a legalização e descriminalização do abortamento veiculados pela mídia impressa brasileira. Com base na perspectiva francesa da Análise do discurso, foram analisadas matérias publicadas entre o período de 2011 a Agosto de 2014 pelo Jornal Folha de São Paulo. Os resultados sugerem que a expressão da aparição da legalização do aborto nos discursos veiculados nas matérias do corpus construído possui possível relação com nuances dos contextos em voga. O ano de 2011, que sucedia a campanha eleitoral para a presidência, contou com tentativas de silenciamento do tema; já o ano de 2012 foi marcado pela liberação do aborto nos casos de anencefalia, contribuindo para o deslocamento do tema para a ótica da Saúde Pública que foi fortalecida no ano de 2013 com o apoio do Conselho Federal de Medicina (CFM). O primeiro semestre de 2014 caracterizou-se pela esquiva dos principais candidatos nas eleições presidenciais. Foram identificados discursos religiosos, sanitários, feministas, midiáticos e eleitoreiros. Buscou-se contribuir para a dis-

\footnotetext{
Mailing address: $\mathrm{Br}$ 040, km 456, Balaios, Caetanópolis, MG, Brazil 35770-000. Phone: (31) 9923-6233. E-mail: thiagomikhael@hotmail.com and albertomesaque@yahoo.com.br
} 
cussão sobre a legalização do aborto no Brasil, sendo necessário refletir sobre o veículo midiático e sua capacidade de legitimação de uma prática que causa controvérsia, mas tem aceitação quando ocorre de modo silencioso e invisível.

Palavras-chave: Aborto, Análise do Discurso, meios de comunicação de massa, Saúde Pública.

\section{La Legalización del Abortamiento en el Discurso del Periódico Folha de São Paulo (2011-2014)}

\section{Resumen}

El estudio buscó analizar los discursos sobre la legalización y despenalización del aborto en los medios de comunicación impresos brasileños. Desde la perspectiva francesa del Análisis del Discurso, fueron analizadas textos publicados en el periódico Folha de São Paulo, en el período de 2011 a agosto de 2014. Los resultados sugieren que la expresión de la aparición de la legalización del aborto tiene una posible relación con matices del contexto en cuestión. El año 2011 ha sucedido la campaña electoral para la presidencia, tuvo intentos de silenciar el tema; el año 2012 estuvo marcado por la liberación del aborto en casos de anencefalia, contribuyendo con lo cambio del tema a la perspectiva de la salud pública que se fortaleció en 2013 con el apoyo de Conselho Federal de Medicina (CFM). El primer semestre de 2014 se caracterizó por la evitación del tema por los principales candidatos en las elecciones presidenciales. Se identificaron los discursos religiosos, sanitarios feministas, mediáticos y electorales. Hemos tratado de contribuir a la discusión sobre la legalización del aborto en Brasil, siendo necesario reflexionar sobre los medios de comunicación y su capacidad de legitimación de una práctica que causa controversia, pero tiene la aceptación cuando ocurre de manera silenciosa y invisible.

Palabras clave: Aborto, Análisis de Discurso, medios de comunicación de masa, Salud Pública

Currently the unsafe abortion represents a public health problem, especially in Latin America where often the criminalization does not stop its practice (Soares, Galli, \& Viana, 2011). In Brazil, the National Abortion Survey (PNA) indicates that, until the age 40, more than one in every five women of the urban area resorted to abortion. The estimated number of annual abortions in the country is approximately 1.4 million, resulting at great expense to the public capital (Bursztyn, Tura, \& Correa, 2009; Diniz \& Medeiros, 2010). In this direction, the unsafe abortion is presented among the five leading causes of maternal mortality and results in physical complications and post-abortion psychosocial (Ministério da Saúde, 2009).

In Brazil the practice of abortion dates back to the colonial period, until 1830 it was treated as a wrongful conducts and thereafter went on to set up a crime with punishment provided only to third parties who practiced (Castelbajac, 2010). Only in the Penal Code (CP) of the 1890 self- abortion was penalized with attenuation of penalties, if it was done to hide the dishonor.

With the change of the Honor paradigm to biopolitical paradigm, we see changes in legislation on abortion in the CP of the 1940, which still exist. It brought legal permissions only for cases where there was a risk of mother's life and in cases of pregnancy resulting from rape (Hentz, 2013).

In the 1970s and 1980s social movements of women and feminists worked in the legalization of abortion based on sexual and reproductive rights, grounded in the principle of autonomy (Bursztyn et al., 2009). The debate on the right to abortion was spreading and adding new instances and social actors allowing some traditional positions such as, "pro-choice" and "pro-life" were consolidated and affirmed by different groups of society by setting up a controversial debate on the legalization of abortion (Hentz, 2013).

One of these examples is the media, in which the abortion issue starts their narrative 
tools for news creation. In this sense, the media functions as a vehicle for reproduction of dialog to reach diverse audiences, whose influence unfolds the national political agenda (Gregolin, 2008). Although the discussion of the media's role in publishing dialogue on abortion is still an emerging theme in the national literature. Existing studies shows dominance on addressing the issue from a moral dilemma (Diniz \& Castro, 2011; Fontes, 2012; Pinho, 2009). These moral views can reflect in the displacement of theme from the perspective of public health.

Whereas the discourse is a social practice and the enunciations that compose it can be considered a correlates of historical-social position (Foucault, 1969/2008; Maingueneau, 1997), and can be expected that the issue of the legalization of abortion appear in speech of the media, taken here as (re)producer of speeches from contexts, institutions and several actors (Gregolin, 2008). This study aimed to analyze the discourses on the legalization and decriminalization of abortion conveyed by the Brazilian media.

\section{Methodology}

With the aim of analyzing the discussion on the legalization and decriminalization of abortion conveyed by the media, there was a qualitative and documental study done, by means of the terms "legalização do aborto", "descriminalização do aborto", "criminalização do aborto", "legalização do abortamento", "descriminalização do abortamento" and "criminalização do abortamento". In the news, stories were published and circulated by the online version of the Journal Folha de São Paulo - one of the largest newspapers circulations in Brazil - between the periods of January 2011 to August 2014, which discuss the issue of legalization of abortion.

In the first stage 152 materials were found and, were submitted subsequently for a preliminary reading in order to select only the texts that had the "legalization of abortion" as a central theme. This criterion allowed the exclusion of 95 subjects, leaving 57 texts which were selected to build the corpus of analysis (Table 1).

Table 1

News Selected in the Online Version of the Newspaper Folha de São Paulo Transmitted in the Years 2011, 2012, 2013 and 2014

\begin{tabular}{llr}
\hline $\mathbf{N}^{\circ}$ & \multicolumn{1}{c}{ Título das matérias } & Data \\
\hline 01 & Archbishop of Brasilia will command one of the 'ministries' Vatican & $01 / 05 / 2011$ \\
02 & New Congress will face old polemics & $01 / 30 / 2011$ \\
03 & CNBB avoid discussing abortion in the 1st meeting with Dilma & $02 / 17 / 2011$ \\
04 & Religious defend legalization of abortion in Argentina & $05 / 31 / 2011$ \\
05 & Movement criticizes projects contrary to female interests & $08 / 18 / 2011$ \\
06 & DEM targeting conservative values to replenish losses to the PSD & $09 / 29 / 2011$ \\
07 & Latin America must respect women's rights, says NGO & $09 / 29 / 2011$ \\
08 & Mississippi voters decide on Tuesday about criminalization of abortion & $11 / 05 / 2011$ \\
09 & Organizational failure generates just quit for Dilma in event & $12 / 12 / 2011$ \\
10 & Women discuss abortion and sexual diversity event in Brasilia & $12 / 13 / 2011$ \\
11 & Senate of Uruguay discussed today about the decriminalization of abortion & $12 / 27 / 2011$ \\
12 & Senate of Uruguay approves legalization of abortion; Camera still vote & $12 / 27 / 2011$ \\
13 & Supreme agenda faces controversy in 2012 & $01 / 01 / 2012$ \\
14 & Political parties try to avoid veto churches in São Paulo & $01 / 16 / 2012$ \\
15 & New Dilma's minister says that the abortion isn’t an ideological issue & $02 / 07 / 2012$ \\
16 & Deputy PMDB criticizes the new minister of the Secretariat for Women & $02 / 09 / 2012$ \\
18 & Dilma says new minister will act 'according to government guidelines' & $02 / 10 / 2012$ \\
\hline & & $02 / 12 / 2012$ \\
\hline
\end{tabular}




\begin{tabular}{lll}
\hline $\mathrm{N}^{\circ}$ & Título das matérias & Data \\
\hline
\end{tabular}

19 CNBB says new minister's position on abortion 'bothered'

$02 / 16 / 2012$

20 Priest Marcelo advocates mobilizing sectors against new minister

$02 / 27 / 2012$

21 Religious return to circulate anti-abortion pamphlets in São Paulo

$03 / 10 / 2012$

22 Justice of Argentina approves abortion for the cases of rape

$03 / 13 / 2012$

23 Catholic anti-abortion return to distribute pamphlet against PT in SP

$03 / 21 / 2012$

24 Spain will resume Law of 30 years ago about abortion, says minister

$04 / 05 / 2012$

STF brand for April 11 judgment about abortion of anencephalic

$03 / 23 / 2012$

Judgment about anencephalic abortion will watershed, says minister

$04 / 10 / 2012$

Anencephalic pregnant has the right not to suffer, says procurator

$04 / 11 / 2012$

Catholic jurists ask that the Senate does not legalize abortion and euthanasia

$08 / 03 / 2012$

Naked, Uruguayan protest against project failures decriminalizing abortion

$09 / 25 / 2012$

Uruguayan deputies approve law project decriminalizing abortion

$09 / 26 / 2012$

Pastor ask for vote for alderman during cult

10/08/2012

32 Uruguay approves abortion for pregnancies up to 12 weeks

10/17/2012

Candidates return to show differences in the dispute for $\mathrm{OAB}$

11/27/2012

Protests mark first decriminalization Day Abortion in Uruguay

$12 / 03 / 2012$

In El Salvador, women can be arrested for having abortion Spontaneous

$10 / 22 / 2013$

States restrict abortion in the United States 40 years after release

$01 / 22 / 2013$

Most Americans support abortion with restrictions

$01 / 22 / 2013$

38 Legalize abortion at 12 weeks 'miseducate' and is 'serious', says Bishop

$03 / 21 / 2013$

Uruguay could discuss abortion law with viability of Referendum

$03 / 21 / 2013$

40 Rule on abortion should only be voted on in the $2^{\text {nd }}$ semester Senate

$03 / 21 / 2013$

Readers repercussions defense medical abortion up to $12^{\text {th }}$ Week

$03 / 23 / 2013$

Deputies and senators try to stop decriminalization of Abortion

$03 / 26 / 2013$

Readers comment on the issue of abortion in Brazil

$03 / 30 / 2013$

44 Silas Malafaia: Marco Feliciano is the flavor of the month

$04 / 05 / 2013$

45 Dilma runs away from polemic to keep peace with evangelicals

$04 / 15 / 2013$

46 Reader criticizes government inaction on clinics that make abortion

$05 / 09 / 2013$

Evangelicals do protest against abortion and gay marriage in Mexico City

$06 / 05 / 2013$

Protest against the Unborn child statute brings together 1,500 people in the square

$06 / 15 / 2013$

49 Feminists protest against sexual violence next to of the WYD pilgrims

$07 / 27 / 2013$

50 Slutwalk criticizes the Catholic Church in Copacabana in Rio; watch

$07 / 28 / 2013$

51 Religious react with new projects to the law which gives guarantees for rape victim

$08 / 09 / 2013$

52 Feminist manifestation interdicts Augusta Street in downtown SP

$08 / 31 / 2013$

53 'Slutwalk' march does march in Ribeirão and calls for end to violence

$09 / 28 / 2013$

54 Slutwalk wants annual protest in Ribeirão Preto (SP)

$09 / 30 / 2013$

55 Pope asks the faithful are not "window of Christians"

$10 / 12 / 2013$

56 Readers comment articles on the legalization of abortion

$04 / 25 / 2014$

57 With controversial proposals PSOL, launches Luciana Genro to the Presidency

$06 / 22 / 2014$ 
The selected news was analyzed from the perspective of current French Discourse Analysis (DA) which in short understands the language as inseparable from the social formation and historical-social processes (Brandão, 2009). Therefore, the DA can be defined as ". . . a field of study which provides conceptual tools for the analysis [of] discourse events, and the effects off the context in its production" (Gregolin, 2008, p. 13). Brandão (2009) complete that the DA is not restricted to a purely grammatical analysis, considering the external aspects of the language, as well as social, historical, ideological and cultural elements that surround and is reflected in the discourse.

Regarding the procedures of the analysis took place. Careful readings of selected texts were done to find out and interpret meanings unnoticed and unspoken. Foucault (1969/2008) points out that, in part, the DA is intended to interpret an "already told" which is simultaneously an "unsaid". Thus, this first step allows seizing words or repetitive terms and possible latent meanings which maintain connection with specific socio-historical contexts that are part of their denunciative scene and speeches from where it contributes.

With the identification of discourses that was aired by media, we tried to study their effects of sense. As recalled Brandão (2009), as a science of interpretation, DA aims to understand the mode of signification of speech, but not on stagnates interpretation, but rather the interrogates. Thus, the corpus of analytical device of the work was assembled using the selected news, academic articles and news, which were primarily aired on government sources, and were analyzed by wondering the conditions of their discursive production - who speaks and from where it speaks. Because what is said is not said anywhere (Brandão, 2009; Foucault, 1969/2008) - relations of power, against whom and whose the interests underlie the discourses identified, being favorable or contrary amid the enunciative scene.

\section{Results and Discussion}

\section{The Enunciative Scene of the Discourses about the Legalization of Abortion (2011-2014)}

It was observed a variation regarding the number of news produced each year. Although, it was considered only in the first semester. The year 2014 was the one with less news and just two materials abortion emerges as the central theme. Compared to other years, 2011 had fewer core subjects (12), subsequently 2012 (21) and 2013 (22).

The lowest amount of news that characterized in the year 2011 seems to be a reflection of certain nuances of the specific context in vogue. As the speech is (re)produced by individuals located in places, scenarios and specific times (Brandão, 2009). Thus in agreement with Maingueneau (1997), so a text is part of an enunciative scene, such as the interpretation and description of his wordings transposes the simple analysis of an author and what he may have said explicitly or implicitly, in order to determine which position every individual can and should occupy to be his subject (Foucault, 1969/2008).

It must be considered that the period selected for the study refers to the later years of 2010 presidential elections, which relied on exploiting the position of candidates of Dilma Rousseff (Workers Party - PT) and José Serra (Brazilian Social Democracy Party - PSDB) on the legalization of abortion which at that time was included in the PT government program (Machado, 2012). But when pressed by the Christian base movements, especially Catholics and Evangelicals. It was Rousseff's government commitment not to legalize abortion by modifying it and including it in the National Human Rights Program - 3 (PNDH-3).

The matter No. 3 , in the title itself expects that, in the first meeting with the President, the National Conference of Bishops of Brazil (CNBB) with whom it was sealed agreement, "spared" the legalization of abortion theme. The term "spared" seems to suggest that, the Church's 
mercy is not pressure on her to talk about a subject "embarrassing", a theme "thorny" as was conveyed in the matter No. 13.

Thus, it seems that the year 2011 demarcates a period of attempts of silencing the theme legalization of abortion that counted a hushed stakeout by the opposing groups. This can be noted in the Secretary General's speech of the CNBB, Bishop Dimas Lara Barbosa: "It seems to me that this issue [Legalization of abortion] has already been closed [our griffon] during the campaign" (No. 03, 02/17/2011).

For the secretary general of the CNBB discussion was already "closed" but observing other events during the two months, his discourse seems to accomplish a try of the levamentum of subject. In March 2011, parliamentarians "pro-life" organized a breakfast in the House of Deputies, aimed at pre-launch of the Mixed Parliamentary Front in Defense ofLife-FPMDV (Movimento Nacional da Cidadania pela Vida - Brasil Sem Aborto, 2011). Thus, FPMDV was officially relaunched in April 2011 and will aim to mobilize the population against the legalization of abortion. Blocking projects with such intention and approve the project called the Statute of the Unborn ${ }^{2}$ (Senado Federal, 2011). Moreover in May 2011, the CNBB allocated a motion of support for FPMDV (CNBB, 2011).

To Maingueneau (2006), the discourse aims to convince instituting a scene of enunciation that legitimizes him. However, in a debate, the members hardly enunciate from their own scenographies, and without the control of enunciation, it starts to react instantly to an unforeseen circumstances provided by the interlocutors. In this logic the CNBB's discourse of silencing seems to operate. Foucault (1970/1999a) had already warned that some Discourses are accompanied by interdiction procedures in a game around the taboo of object - whose boundaries are more ten-

2 It is a law project (No. 478/2007) which provides full protection to the unborn child - a human being conceived and yet unborn. To this end, it seeks to convert into crime any type of abortion - legal and even the use of embryos in scientific research - and providing a pension for women who become pregnant by rape. uous in sexuality issues. The CNBB's speeches excludes a debate that actually finds support in the organization of FPMDV. Like the Folha treats the subject as "polemic".

In Foucault's perspective (Foucault, 1976/1999b), Barbosa's discourse can also be considered as repressor. The author recalls that repression works especially as a condemnation of the disappearance injunction to silence or assertion inexistence, causing the finding there is nothing to say, see or to know.

The year 2011 also counted with the fourth edition of the movement of March of the Daisies. The second day of the march, the representatives were received by the Permanent Subcommission on Defense of Women (SPDM) in the Senate, where they presented "critical" to the projects contrary to the "feminine interests". According to national secretary of Working Women of the Central Workers Union (CUT), Rosane Silva, who had his speech reproduced by Folha ("Movimento critica projetos", 2011) in the news No. 05:

The woman is required to be a mother. We have no right in this country today to decide on our bodies, to decide whether we want to or do not want to be a mother. And those projects that are now under consideration in Congress not only criminalize us but also lead millions of women to death . . .

Even though the sheet did not specify the projects "contrary to the feminine interests" who seek to toughen the abortion legislation, such as the Statute of the Unborn. At that time, this social movement had rejected projects in the National Congress that considered the abortion as a hideous crime; complete interdiction of this practice and the Statute of the Unborn (Congresso Nacional, 2011).

In late 2011, maternal and child focused policies were targets of rejection of feminist movements. In this part, the news No. 09 treats to narrate the $3^{\text {rd }}$ National Conference on Policies for Women included the participation of President Dilma. Concerning the measures criticized by feminists during the event. The Folha quoted the Stork Network (RC) which focuses on maternal health. She adds that "... the focus 
given to maternal health to the detriment of 'reproductive health' of women ... would play under the rug of discussion about the legalization of abortion in Brazil" (Foreque \& Nublat, 2011).

The Feminist Health Network and the CNBB were the only two representatives of civil society at the launch of RC. Incidentally, the FPMDV also came to support and present the strategy one day before being released. For Machado (2012) this fact shows a mutual relationship between the religious sector forces, segments of ecclesiastical institutions and alliances with the state. Pinto (2013) notes that both the RC and Provisional Measure 557/2011. There is concern for the monitoring all pregnant women served by the Unified Health System (SUS), which would allow to inhibit the termination of pregnancy. One might think that the old vigil and ecclesial pedagogy of the Colonial Brazil confessors were moving, until the health strategies goes according to the religious discourse on motherhood, life and family. Especially in the axis of motherhood and family. The Christian pastoral has been working directly because the classical Christianity arises holding up the device of alliance and its own rules. But today it is he who strives to sustain this old device (Foucault, 1976/1999b).

Early on in 2012 the presence of the "abortion decriminalization of anencefalous", it was already disseminated as one of the schedule of the Supreme Court (STF). In the first article on the subject (No. 13), once again the decriminalization of abortion appears as a "polemic".

It is worth highlighting that in the passages accusation of breach of fundamental precept (ADPF-54), stated:

Search-if only those statements [criminal offenses] are interpreted according to the Constitution ... Appears to be entirely unreasonable to vehicular which the Supreme examine ... the decriminalization of abortion [our griffon] . . . exists distinction between abortion and therapeutic anticipation of parturition (Aurelio, 2012, p. 30).

Despite the Folha (Agência Brasil de São Paulo, 2012) have used the term "decriminalization of abortion" the reporter of the ADPF-54 was categorical regarding the purpose of the trial. But, as the word abortion is already saturated with ideological meanings in dispute by groups with opposing positions in the debate over its legalization. And the media is an essential space among these groups with influence in political decisions (Lemos, 2013).

Although Folha appears to delegate the abortion of anencephalic fetuses, adjunctive paper in the formation of the STF image, Minister Cezar Peluso, who chaired the session, has referred it as "the most important in the history of the Supreme" (Marcello, 2012). Already in another article published closer to the date of the tribunal (No. 26), the Minister Ayres Britto said: "the country had an appointment with this theme. It is a watershed in terms of public opinion, reflected a lot in the field of religion, public health. A great theme for its impact...”.

The Talk of Britto refers to the arrival of the theme to court since 2004, and it attributes in the anticipation of childbirth in cases of anencephaly resonance in the areas of religion and public health from the perspective of a conception of "life" modifiable. In this sense, in 2012, the domain of religiosity and Public Health does seem to dictate the tone of national discourses about the legalization of abortion.

Returning the legalization of abortion to the position of "polemic", the Folha (Agência Brasil de São Paulo, 2012) declares: "the polemic seems far from over". The excerpt suggests the close relationship between the stability of thought "polemic" and its entity whose religious lobbies had restricted participation in the trial process (Aurélio, 2012). We should consider Folha, it begins with a discourse of neutrality, not recognizing their role in the maintenance, classification and interpretation of topic on the bias of "polemic". However, Pinho (2009) reinforces the idea that, in addition to determine the subject of debate, the media also determines which interpretations are valid in the discussion of an issue.

In relation to the public health, there was contention about the connotative sense of the word "abortion". Lemos (2013) recalls that in a dialogue, the words are not neutral and there is a battle for its meaning, not only as a sin but 
also as a question of health or rights. This can be observed in the news No. 15, in the discourse of Eleonora Menicucci, new Minister of Secretariat on Policies for Women (SPM): "The abortion . . . is a question of public health, not an ideological issue [our griffon]. Like as crack, drugs, dengue, HIV, all infectious diseases".

This consignment of minister Menicucci was rejected by the religious sectors engaged in the criminalization of abortion. According to deputy discourse of Eduardo Cunha (PMDB) in the news No. 16, the image of the minister is associated with sin:

... Menicucci is in place at the wrong time

... she should be in Sodom and Gomorrah .

.. this possession of abortionist tomorrow is symptomatic for all of us and we must show forcefully our revolt. ABORTION NOT!

The SPM's minister of discourse was also rejected by the Chamber of Deputies of the parliamentary Eros Biondini (PTB-MG), Manato (PDS-ES) and Pastor Eurico (PSC-PE) from the religious perspective (Congresso Nacional, $2012)$. On the same date $(16 / 02 / 2012)$, in news No. 19, in his discourse, the Secretary General of the CNBB Bishop Leonardo Steiner says:

[The positioning Menicucci] bothered a lot of people, not only the CNBB. But I make a distinction, she made a personal pronouncement, afterward said it was not the government's position. We would like to reaffirm that the issue of abortion cannot be understood as an ideological issue [our griffon]. We put as the meaning of human life.

In the discourse of minister, the legalization of abortion appears on the prerogative that "no one person in management having sensitivity and have listening of the numbers admits that the women remain dying as a result of abortion". Although not quoting the numbers, she tried to base her empirically discourse to give materiality and reality to abortion as a public health problem, an conception of ideology analogous to the Marxist understanding in which ideology consists of ideas and illusory value system that mask the social reality (Brandão, 2004). Already in discourse of Steiner, as usual in Christian spheres it can be refer as an another sense of ide- ology, in which the meaning of life is not part, even because life for the anti-abortion Christian groups is a transcendent principle (Almeida \& Bandeiras, 2013).

As discourse of archbishop from Sorocaba Don Eduardo Benes, on the website of the CNBB (Rodrigues, 2012) there is partial agreement with the discourse of Menicucci:

I agree [is not ideological issue], but with opposite conclusions . . . public power should fight . . . with rigor the owners of clandestine clinics and providing medical care for all pregnant women so they are not vinctims of the violence of abortion. Why not be an ideological issue, but an ethical issue, it is the duty of everyone, especially of governments, to employ all means [our griffon] to banish from society so heinous practice.

The archbishop's discourse accepts that all means are employed in the extinction of abortion practice, which reinforces the sensitivity of religious institutions to the theme. Still in the SPM Minister pronouncement, the priest Marcelo Rossi said in news No. 20: "There are principles that govern the church, and if it violates their mobilization. Or if a candidate is in favor of abortion, not just me, but also evangelical sectors, will mobilize against". This discourse seems to consider that the principles of the Church are above constitutional provisions, since it understands that the position in favor of legalization of abortion violates religion, disregarding the laic character of the state in Brazil.

Certainly the conflict between the discourse of the minister and religious brings out a typical polarity between the groups termed "pro-life" and "pro-choice". Originally derived from the US case in 1973, in which the young Jane Roe fought for the right to abortion in Texas (Borsari et al., 2012), these categories have emerged in the Brazilian scene in around decades 1970 and 1980. Aiming the debate initiated by the feminist movement about the legalization of abortion (Hentz, 2013). The main differences relates to the rights of women and unborn life, the beginning of life, the legitimacy and constitutionality of the practice of abortion. How- 
ever, both the arguments "pro-choice" as those "pro-life" can be based on the same legal provisions and field knowledge. This is because they are not necessarily the different areas of knowledge or the respective legislation responsible for different perspectives about abortion, but eventually the morality of each group seeks to reconcile juridical, medical and religious discourses to the viewpoint that defends (Valpassos, 2011).

As well as in the 2010 presidential elections, the municipal elections of 2012 counted on the airing of pamphlets recommending not vote for candidates "pro-abortion". As the discourse (No. 23) of the Bishop of Guarulhos, Bishop Luiz Bergonzini: ". . . we prove that the PT and Dilma Rousseff were and are in favor of the release of abortion". For the religion, this proof lay in hiring of Eleonora Menicucci minister.

Thus the year 2012 was marked by the dispute, and above all, by the sense of the word abortion. The possible displacement of issue to the field of Public Health appeared in the vision of opposite sectors were likely to be a threat to legalize abortion, pressing Menicucci in reducing his discourse of "personal opinion" (No. 15) reiterating the government's position in this case and the commitment of President Dilma with the religion: "My personal position is in all papers . . . but my government; my position [our griffon] today is of government".

Since October 2011, began a CP Review process, which from then on was prepared as a draft bill in March 2012 by a commission of jurists established by Senate (Senado Federal, 2013). Due to the content of the proposals contained in the text of the draft bill CP (PLS 236/2012) appears too have sedimented the polarization between the favorable groups and the groups who opposed the legalization of abortion. Through Circular No. 46/2013 of the Federal Council of Medicine (CFM), Roberto d'Avila, after the First National Meeting of Medical Council (ENCM) 2013 in Bethlehem, proclaimed the official position of the most favorable advice to autonomy of women and the expansion of criminal exceptions in cases of abortion (CFM, 2013a).
The Federal Council of Psychology (CFP) had also positioned itself in favor of the legalization of abortion since the arrival of the CP reform draft bill to the legal committee organized by the Senate and supported the decision of the CFM, recognizing its progress, mainly due to its position is primordially based on the will of the woman (CFP, 2013; Pires, 2013). On the other hand, this dimension is neglected in the position of president of CRM-MG, João Batista Soares: “. . there are special situations that justify [abortion]. Now, just because the woman did not want to have that child, then we are against" (No. 41, 03/23/2013).

In the news No. 38, the bishop of the CNBB, Carlos Petrini, moralized the CFM pronouncement:

What we consider serious in this context is the educative power - which has a negative educational, really - . . the Federal Council of Medicine has the power to create mentalities . . otherwise, strengthens a mentality that favors the recourse to violence and death... In a context where Brazil is beset by violence rates that put us in a similar situation with countries that are at war.

The speech of the bishop seems to assign a character of anti-pedagogical to positioning CFM, but as what is said is not said from anywhere (Foucault, 1969/2008), he does not speak for any of education, but of a Christian education, because the Church opposes the use of contraceptive methods, and is especially resistant to sex education in schools. The National Family Week (SNP), the virtual page of the CNBB (2013) contained a text which presented the main challenges in Christian education:

[One of the challenges] lies in the manner of conceiving the human being threatened by the dictatorship of relativism . . . The consequences of not correspondence to God's plan they are disastrous for the person, family and society. This explains the justification of abortion as a woman's right [our griffon], the attempts to legalize euthanasia, artificial birth control, laws increasingly permissive divorce, extramarital relations, homoafetivas unions and other. 
In discourse, the support for legalization of abortion breaks with the "God's plan" - to whom belongs the power over life and death. In reality, abortion was considered a sin and not a homicide. Bursztyn et al. (2009), recall that the radicalization of the position of the Catholic Church dates back to 1995 - the occasion in which Pope John Paul II admonished modern society about the emergence of a "culture of death", indicating that abortion could not be legalized. The association of abortion to violence at Petrini's discourse brings a conception that does not include institutional violence suffered by women (mostly Catholic and religious) practiced by health professionals who are oriented from their beliefs and try to impose them (Soares et al., 2011).

Historically medicine had its image associated with religion and the Church. Foucault (1961/1978, 1979/2001) recalls that medicine was linked to religious institutions, and the first general hospitals were derived from monastic establishments and, only then by linking to State could establish a "healing art" or even understood as biopolitics strategy. Thus, it's possible to think of a doctor's social image as the savior of lives, so that, where abortion is understand as "homicide", and the doctor is seen as he is doing a service of death.

Thus, in the present, the life is positioned with a paradigm (Hentz, 2013), but when encountering with the empirical reality of abortion, the medical reference corporations are compelled to take a stand. Of course, part of medicine also seeks to move away from a hygienist and moralistic image of "militant positivism" in the words of Castelbajac (2010). Yet, one should consider that in the early twentieth century, the incipient medicine in Brazil helped in assimilation of women to maternity as a destination. This movement is especially part of a technology of sex formed in the late eighteenth century, it was not fully independent from religious themes, but it escaped the ecclesiastical institutions, so that medical practice aligned itself up to demographic interests, fighting essentially against the "frauds against procreation" and "against nature" (Foucault, 1976/1999b).
This position, however, appears to cause surprise, as the speech of one of the readers (No. 41) Folha ("Evangélicos fazem protesto", 2013): If doctors are positioned against life, it is a sign of a serious subversion of values that fortunately does not seem to have even contaminated the Brazilian people ... The doctors have more obligation of knowing, that we are talking about the fertilization of a human being ...

The reader's discourse seems to try to adjust the medical image to the position with which it broke, because society still finds it difficult to assimilate the justifications for legal abortion, especially by physicians (Carvalho, Gonçalves, \& Carvalho, 2013). Ambiguously, the reader conceives some authority to doctors to speak about life, but ends up put himself above them and want to remind them about the origin of human life.

According to the news No. 42, leaders of religious benches of Congress requested clarification by d'Avila:

We want him to come to the committee for debate by putting the reasons why he came to that decision... And who made him to make that decision . . . at three months, you will take out a fetus in pieces to throw in trash... It is a murder that exists in mass in Brazil. . . . We have to criminalize those who commit crime conscious. This proposal is infamous because it is calling for legalizing crime [our griffon].

In fact, about six days before (03.21.2013) portal CFM (2013b) had already issued a note clarifying its approval about legalization of abortion. The note also mentioned the CFM discussion with the 27 regional medical advice two years ago. Thus, the discourse of evangelical Senator Magno Malta (PR-ES) shows a partial flexibility and willingness to debate that had claimed, since its vision conveys crime as "natural". For it is necessary to "criminalize" it even what is already "crime" as if crime always existed preceding the criminality that is so denominates.

One should also add that, Malta articulates the religious countertops, seeking to stop the 
$\mathrm{CP}$ reform bill, and also organize protests in the next two months ("Evangélicos fazem protesto", 2013). To Barreras and Weber (2014) religious activism, which have clearly defined leaders, and were occupying the public environment punctually in maintaining its values and defend their flags. On that occasion, the Statute of Unborn was approved by the House of Representatives. But in the same month other movements composed by the Brazilian League of Lesbians, the Slutwalk and the World March of Women also organized manifestations engaged in the legalization of abortion.

The Slutwalk fits into the context Appropriate, since in August 2013; the President Dilma sanctioned the Law No. 12,845 that offers a mandatory and integral care of people in a situation of sexual violence (Lei $\left.N^{\circ} 12.845,2013\right)$. Among the services covered, the "Prophylaxis of pregnancy" that offers the pill of emergency and information about the right to abortion for the rape victim, which reverberated in the Chamber of Deputies between evangelical members.

It is suspected that the preparation "of the political and legal scenario for the complete legalization of abortion in Brazil" (Pastor Eurico - PSB-PE; No. 51, 08/09/2013). Because, on one hand it was the Statute of Unborn and on the other, the law $\mathrm{N}^{\circ} 12845$ and the draft bill in which the Folha (No. 40) had already announced, and did not have a strong reception, even with the support of CFM. In this news Folha reminded by Pedro Taques position - "in favor of life" - which in the final draft bill text did not differ. In full, Taques said that it would be based on the unconstitutionality of Article that allows abortion according to the desire of the pregnant woman, but in Magno Malta page it says that "Pedro Taques upheld the religious arguments" (Malta, 2013). It reads as follows: "With regard to abortion, the approved report, Senator Pedro Taques, has already assisted the Family Front. However, while the text is not adopted in plenary, one can stand out and change everything. That is why we are vigilant".

Since the year 2013, President Dilma demarcated an ambivalent positioning in relation to the demands of religious and women's move- ments. For Folha (No. 45), Dilma and the Planalto "flee" themes "polemical":

Dilma has positioned itself in favor of decriminalizing abortion, but changed his mind in the election campaign. The Planalto Palace expects ... [the issue is not central] in the dispute for 2014, which would decrease the weight of the evangelical demands in the election race.

Due to the year of presidential elections, the legalization of abortion issue had reduced its appearance and with the exception of the news No. 57, in which Luciana Genro (PSOL) inserted the guideline in his program:

She intends to take the electoral debate themes considering polemical, and therefore is avoided by the main presidential candidates. Luciana will defend the decriminalization of marijuana, the guarantee of $L G B T$ rights and the legalization of abortion as a public health policy.

Being aware of the rejection by the society and religious sectors, the "prime candidates" seems to have avoided the subject, by not permitting the immediate positioning. Without affecting the campaign dividing the electorate, electoral marketing considers the legalization of abortion is a taboo (Barreras \& Weber, 2014).

In an interview with Folha, in May 2014 ("Leia a transcrição da entrevista de Aécio Neves"), presidential candidate Aécio Neves (PSDB) had stated laconically: "[be in favor of] current rules [about abortion]". Already in another interview of Folha (Rodrigues, 2014), presidential candidate for the PV, Eduardo Jorge, criticized the position of opponents about the abortion:

... Using [Dilma, Aécio and Campos] a biblical language, they are entering as Pilate of history. They are washing their hands, because that is not their own position. They know very well the women's drama ... That [are lying]. Or lie or omit. I do not know which is worse.

In the aforementioned discourse, Jorge compares the positioning of the presidential candidates to biblical character Pontius Pilate, and seems to suggest that the position of can- 
didates keeps harmony with the conservative sectors, such as in the 2010 elections (Fontes, 2012). With the further diffusion, visibility and hegemony of Christian religiosity in the media to detriment others, in conjunction with the silencing of government and lack of decisions of the executive and legislative, Barreras and Weber (2014) envision the neutralization of the public debate is necessary, the broadcasting of arguments and opinions are barely visible, organizations such as Catholics for a Free Choice, the Brazilian Center for Health Studies (CEBES) and the Study Group on Abortion (GEA).

\section{Religious Discourse}

Regardless of their forms of linking with politics, the discourses of the Catholic and evangelical religion are the most hegemony in the analyzed corpus. The legalization of abortion on religious discourse appears as a measure "infamous" that have the use of death and violence. This connotation attributed to the legalization of abortion has possible link with the religious conception of the groups "pro-life", in which the meaning of life transcends ideological character and articulates with the divine plan.

Thus, religious discourse signs up as holder of the absolute truth and therefore, possessor of the patent of ethics and morals. Despite the authoritarianism that this discourse implies, it is not recognized as such, because it is to forget the very act of its origin (Foucault, 1970/1999a). This discourse also seems to deny and rewind to a past in which notables representatives of the Church were complacent with the practice of abortion.

As holders of the absolute truth, according with Foucault (1970/1999a, p. 22) the religious discourses, ". . . over and above their formulation are said indefinitely, remain said, and are to be said again". This characteristic creates a prophetic tone to the discourse, according to which the legalization of abortion is "deseducaria" because it flees the legitimate use of sex - procreation - and would stimulate women to sin on a defenseless being and the fruit of the divine plan by degrading the value of life and family.

\section{Sanitary Discourse}

The use of statistical techniques leads to the production of a norm (Foucault, 1976/1999b, $1969 / 2008$ ) about the frequency of abortion morbidity and mortality due to this practice, in front of which every discourse proposes a procedures to be realized from certain assumptions. Analyzing the corpus of materials was observed with the existence of at least two types of health discourses: the discourse of harm reduction and the hygienist discourse, both were uttered mainly by academics and health professionals.

The representativeness of "numbers" shows the ineffectiveness of the legal norm on abortion and it does not prevent the damage to the health and life of the pregnant woman nor the fetus. Thus, the legalization of abortion appears as a measure capable of reducing the damage resulting from the criminalization of the practice, which also affects on reproductive autonomy of women over their own bodies.

The hygienist discourse, can also be termed because it proposes hardening of the law and stronger enforcement, as if he wanted to purify the social space, by eliminating what causes him unhealthiness (Castelbajac, 2010). It cause unhealthiness because it perpetuates irresponsibility, as liberate abortion would be "irresponsible certificate" according to Taques (2013) legalizing it can cause disorder. Thus, this practice does not have causality derivative of the current policy, in its broad sense - coexisting with the variety of contraceptive methods but of irresponsibility, ineptitude and denial of motherhood.

We observed a minimization and emptying of the psychological and subjective aspects, like the desire, autonomy and the Probably of reducing these elements; it is that this discourse creates conditions to deny the possibility which then justify the expansion of abortion hypotheses. In addition, the use of the word "child" to refer to the embryo or fetus, suggests the conception of femininity directed to motherhood, as it anticipates its role that cannot be overlaid by the mere desire whose potential in the causation of psychic suffering is underestimated. By the 
disqualification of subjectivity this argument can be placed, as it has influence in the cases of rape and anencephaly (Aurélio, 2012).

\section{Feminist Discourse}

The feminist discourse also shows in the present analyzed corpus. In this, the legalization of abortion appears as a way to extend rights about her own body and reproduction. Thus the legalization of abortion would enable as a break with social norms resulting from historical and social domination of males over females, especially the ones who rebuke or fixing women to maternal role through public policies with maternal and child focus.

In this discourse, which since 1970 has won the adhesion of the movement of women and more recently the Slutwalk, there is a critical declared to machismo which hinders the greater participation of women in politics, of which the law of abortion is considered a reflection.

\section{Media Discourse}

In a lot of analyzed news, the legalization of abortion appears in the discourse of the Folha as a theme "polemical" and "prickly". Thus, the legalization of abortion comes up in the discourses reproduced by Folha as an object of dispute and controversy between actors, groups and contrary institutions, so that the debate tends to appear polarized manner. It emphasizes the reproduction of discourses that collide with other discourses, such as the feminist discourse, electoralist and religious, or between the sanitary discourses. It appears to from this narrative scene that the Folha builds the title of "polemical".

With regard to the polarity around for groups closest to the ideas of "pro-choice" and others, the ideas "pro-life", it can create difficulties. One such difficulty warns Sagan (1998) the automatic distribution of arguments and discourses on one side of the debate, preventing it from being seen consensual forms (Barreras \& Weber, 2014). Pires (2013) remember that CP's review about abortion was not the theme. For example, a radical liberation of this practice with a norm whose time set for interruption of pregnancy until the $12^{\text {th }}$ week of gestation was based in the presence of greater risk involving the abortion in advanced periods and the formation of the central nervous system (CFM, 2013a).

Officially, the Folha de São Paulo ("Aborto: O que a Folha pensa", 2014) declares itself contrary to the criminalization of abortion, but warns to readers that regardless they agree or not, it publishes different opinions. In this sense, it must show publication about other positions, but in doing so, the connotation as polemical goes to derive exclusively from the clash between the contrary discourses that are aired without the interference of Folha has visibility, which creates the impression of your discourse being neutral. However, Barreras and Weber (2014) realize that the media has the power to authenticate above all, the guidelines produced in the press, which allows for contest this impression.

\section{Electoralist Discourse}

Facing the possibility of division of the electorate through the design of position about legalization of abortion, in this theme, the analyzed period was treated for moderate manner of political candidates. Seeking acceptance of conservative sectors and the progressive sectors, there is an electoralist discourse aimed at obtaining and maintaining votes, which is reflected in ambiguous placements.

This discourse is criticized by religious, feminist and other candidates, because on issues such as the legalization of abortion, attempting to accommodate the demands of a part of the electorate, imply in renunciation of demands of another part, resulting in ambivalence and expanding demand of the laicity of State (Machado, 2012).

\section{Final Considerations}

The practice of abortion was present in history from the most remote civilizations, shifting from a private affair to an object of disputes among different groups. In its extreme form, this dispute takes the form of a polarity between of 
groups "pro-life" and "pro-choice" whose discourses have visibility in the media. The media (re)produces discourses about this topic that are aired transmitted in the news, and its expression may be related to the nuances of each period.

The year 2011 succeeded the election campaign and the theme faced attempts of silencing by religious sectors. Already the period of 2012 was marked by the Supreme Court's decision in favor of the liberalization of abortion in cases of anencephaly, contributing to the displacement of the issue to the sphere of public health that was strengthened in 2013 with the CFM unpublished position to underpin the preliminary draft reform of $\mathrm{CP}$ that intensified the confrontation with the groups opposed to the legalization of abortion, so that the first half of 2014 counted with the avoidance by the presidential candidates to this theme.

The main discourses which published: religious discourse, that associates the legalization of abortion to a sordid proposal, violent, murderous of life of an innocent being; sanitarily discourse of harm reduction, that through legalization of abortion seeks to minimize the impacts of criminalization of this practice; hygienist sanitary discourse that seeks to maintain the criminalization of women not to disseminate the irresponsibility that surrounds the abortion; feminist discourse, which sees the abortion legalization as a possibility of break with consequences left by the machismo; electoralist discourse in which legal abortion is vote trading object and of alliances with different groups of society. Finally, the discourse of the media itself that proposes to neutrality, but it seems to play a role in building the theme under the title of "polemical" and a clash between opposing sectors.

Although media has presented the debate to the general public, discourses (re)produced by Folha de São Paulo, It point to the prospects that are presenting the subject as polemical or taboo, which implies the need for reflection about this vehicle and your possible interference in the legitimization of an social practice that has acceptation when it occurs quietly and invisibly, in the hegemonic ways of acting and thinking; in setting the agenda for public health.

\section{References}

Aborto: O que a Folha pensa. (2014, August $\left.1^{\circ}\right)$. Folha de São Paulo. Retrieved from http://www1.folha.uol.com.br/multimidia/ tvfolha/2014/08/1493937-aborto-o-que-a-folhapensa.shtml

Agência Brasil de São Paulo. (2012, April 10). Julgamento sobre aborto de anencéfalos será divisor de águas, diz ministro. Folha de São Paulo. Retrieved from http://www1.folha.uol.com.br/ cotidiano/1073919-julgamento-sobre-abortode-anencefalos-sera-divisor-de-aguas-diz-ministro.shtml

Almeida, T. M. C., \& Bandeira, L. M. (2013). O aborto e o uso do corpo feminino na política: A campanha presidencial brasileira em 2010 e seus desdobramentos atuais. Cadernos Pagu, 18(41), 371-403. doi:10.1590/S010483332013000200018

Aurélio, M. (2012). Arguição de descumprimento de Preceito Fundamental 54. Supremo Tribunal Federal.

Barreras, S. B., \& Weber, M. H. (2014). A neutralização do debate sobre o aborto o ativismo político-religioso e o silenciamento do governo. Compós, 1-21. Retrieved from www.compos. org.br/encontro2014/anais/...E_POLITICA/ compos 2176.pdf

Borsari, C. M. G., Nomura, R. M. Y., Benute, G. G., Nonnenmacher, D., Lucia, M. C. S., \& Francisco, R. P. V. (2012). O aborto inseguro é um problema de saúde pública. FEMINA, 40(2), 63-68. Retrieved from http://files.bvs.br/ upload/S/0100-7254/2012/v40n2/a3094.pdf

Brandão, H. H. N. (2004). Introdução à análise do discurso $\left(2^{\text {nd }}\right.$ ed.). Campinas, SP: Editora da Universidade Estadual de Campinas.

Brandão, H. H. N. (2009). Analisando o discurso. Museu da Língua Portuguesa, 1-28.

Bursztyn, I., Tura, L. F. R., \& Correa, J. S. (2009). Acesso ao aborto seguro: Um fator para a promoção da equidade em saúde. Physis: Revista de Saúde Coletiva, 19(2), 475-487. doi:10.1590/ S0103-73312009000200013

Carvalho, J., Gonçalves, D. W. P. O., \& Carvalho, H. (2013). A legalização do aborto em casos de anencefalia no Brasil. RIDB: Revista do Instituto do Direito Brasileiro, 2(4), 2791-2830. Retrie- 
ved from http://www.idb-fdul.com/uploaded/ files/2013_04_02791_02830.pdf

Castelbajac, M. (2010). Aborto legal: Elementos sociohistóricos para o estudo do aborto previsto por lei no Brasil. Revista de Direito Sanitário, 10(3), 39-72. doi:10.11606/issn.2316-9044. v10i3p39-72

Conferência Nacional dos Bispos do Brasil. (2011). Moção de apoio à Frente Parlamentar Mista em Defesa da Vida-Contra $o$ Aborto. Retrieved from http://www. cnbb.org.br/index.php? option $=$ com docman\&view $=$ document\&alias $=1398$-mocaode-apoio-a-frente-parlamentar-mista-emdefesa-da-vida-contra-o-aborto\&category slug $=$ documentos \&Itemid $=252$

Conferência Nacional dos Bispos do Brasil. (2013, August). Vida e Família: Semana Nacional da Família: Desafios na educação cristã/católica dos filhos. Retrieved from http://www.cnbb. org.br/index.php?option=com_content\&view $=$ article\&id=12617:semana-nacional-da-familia-desafios-na-educacao-cristacatolica-dos-filhos\&catid=196\&Itemid $=179$

Congresso Nacional, Câmara dos Deputados. (2011, April 8). Ata da $61^{\mathrm{a}}$ sessão da câmara dos deputados, extraordinária, matutina, da $1^{\mathrm{a}}$ sessão legislativa ordinária, da $54^{\mathrm{a}}$ legislatura, em 7 de abril de 2011. Diário da Câmara dos Deputados, 66(57). Retrieved from imagem.camara. gov.br/Imagem/d/pdf/DCD08ABR2011.pdf

Congresso Nacional, Câmara dos Deputados. (2012, February 16). Ata da $12^{\mathrm{a}}$ sessão da câmara dos deputados, extraordinária, matutina, da $2^{\mathrm{a}}$ sessão legislativa ordinária, da $54^{\mathrm{a}}$ legislatura, em 15 de fevereiro de 2012. Diário da Câmara dos Deputados, 67(18). Retrieved from imagem.camara. gov.br/Imagem/d/pdf/DCD16FEV2012.PDF

Conselho Federal de Medicina. (2013a). Circular $C F M N^{\circ}$ 46/202013. Brasília, DF: Author. Retrieved from https://waldircardoso.files. wordpress.com/2013/03/ofc3adcio-circularcfm-46-2013.pdf

Conselho Federal de Medicina. (2013b, March 21). CFM esclarece posição a favor da autonomia da mulher no caso de interrupção da gestação. Retrieved from http://portal.cfm.org.br/index. php?option $=$ com_content $\&$ view $=$ article $\&$ id $=$ 23663:cfm-esclarece-posicao-a-favor-da-autonomia-da-mulher-no-caso-de-interrupcao-da-gestacao\&catid $=3$
Conselho Federal de Psicologia. (2013). Notícias: Aborto. Retrieved from http://site.cfp.org.br/ posicionamento/

Diniz, D., \& Castro, R. (2011). O comércio de medicamentos de gênero na mídia impressa brasileira: Misoprostol e mulheres. Cadernos de Saúde Pública, 27(1), 94-102. doi:10.1590/ S0102-311X2011000100010

Diniz, D., \& Medeiros, M. (2010). Aborto no Brasil: Uma pesquisa domiciliar com técnica de urna. Ciência \& Saúde Coletiva, 15(1), 959-956. doi:10.1590/S1413-81232010000700002

Evangélicos fazem protesto contra o aborto e o casamento gay no DF. (2013, June 5). Folha de São Paulo. Retrieved from http://www1.folha. uol.com.br/cotidiano/2013/06/1290466-evangelicos-fazem-protesto-contra-o-aborto-e-ocasamento-gay-no-df.shtml

Fontes, M. L. A. (2012). O enquadramento do aborto na mídia impressa brasileira nas eleições 2010: A exclusão da saúde pública do debate. Ciência \& Saúde Coletiva, 17(7) 1808-1812. doi:10.1590/ S1413-81232012000700019

Foreque, F., \& Nublat, J. (2011, December 12). Falha de organização gera saia justa para Dilma em evento. Folha de São Paulo. Retrieved from http://www1.folha.uol.com.br/poder/1020395falha-de-organizacao-gera-saia-justa-paradilma-em-evento.shtml

Foucault, M. (1978). História da Loucura na Idade Clássica $\left(6^{\text {th }}\right.$ ed.). São Paulo, SP: Perspectiva. (Original work published 1961)

Foucault, M. (1999a). A ordem do discurso ( $2^{\text {nd }}$ ed.). São Paulo, SP: Edições Loyola. (Original work published 1970)

Foucault, M. (1999b). História da sexualidade: A vontade de saber (13 ${ }^{\text {th }}$ ed.). Rio de Janeiro, RJ: Graal. (Original work published 1976)

Foucault, M. (2001). Microfisica do poder (16 ${ }^{\text {th }}$ ed.). Rio de Janeiro, RJ: Graal. (Original work published 1979)

Foucault, M. (2008). A arqueologia do saber $\left(7^{\text {th }}\right.$ ed., L. F. B. Neves, Trans.). Rio de Janeiro, RJ: Forense Universitária. (Original work published 1969)

Gregolin, M. R. (2008). Análise do discurso e mídia: A (re)produção de identidades. Comunicação, Mídia e Consumo, 4(11), 11-25. doi:10.18568/1983-7070.41111-25 
Hentz, I. C. (2013). A honra e a vida: Debates jurídicos sobre aborto e infanticídio nas primeiras décadas do Brasil republicano (1890-1940) (Master's thesis, Universidade Federal de Santa Catarina, Florianópolis, SC, Brazil).

Lei $\mathrm{N}^{\circ}$ 12.845, de 1 de Agosto de 2013. (2013, August 2). Dispõe sobre o atendimento obrigatório e integral de pessoas em situação de violência sexual. Diário Oficial da União. Retrieved from http://www.planalto.gov.br/ccivil_03/_ato20112014/2013/lei/112845.htm

Leia a transcrição da entrevista de Aécio Neves à Folha e ao UOL - Parte 1. (2014, May 22). Poder e Política. Folha de São Paulo. Retrieved from http://www1.folha.uol.com.br/poder/ poderepolitica/2014/05/1458120-leia-a-transcricao-da-entrevista-de-aecio-neves-a-folha-e-ao-uol---parte-1.shtml

Lemos, L. C. (2013, September 16-20). Aborto na mídia: Uma análise de ideologia. Anais eletrônicos: Seminário Internacional Fazendo Gênero, 10.

Machado, M. D. C. (2012). Aborto e ativismo religioso nas eleições de 2010. Revista Brasileira de Ciência Política (Brasília), 3(7), 25-54. doi:10.1590/S0103-33522012000100003

Maingueneau, D. (1997). Novas tendências em análise do discurso ( $3^{\text {rd }}$ ed.). Campinas, SP: Pontes.

Maingueneau, D. (2006). Cenas da enunciação. Curitiba, PR: Criar Edições.

Malta, M. (2013). Frente em Defesa da Familia luta para melhorar mudanças no Código Penal. Retrieved from http://www.magnomalta. com/portal2/index.php/outras-notas-mainmenu-45/2886-frente-em-defesa-da-familia-luta-para-melhorar-mudancas-no-codigo-penal

Marcello, M. C. (2012, April 12). STF aprova legalização de aborto de anencéfalo. Retrieved from http://br.reuters.com/article/topNews/idBRSPE83C00420120413

Mikael-Silva, T., \& Martins, A. M. (2015). A legalização do aborto no Brasil ao longo da história: Avanços e desafios. Revista Venezolana de Estudios de la Mujer, 20, 197-214. Retrieved from http://saber.ucv.ve/ojs/index.php/rev_vem/issue/view/1090/showToc

Ministério da Saúde. (2009). Guia de vigilância epidemiológica do óbito materno. Brasília, DF: Author.
Movimento critica projetos contrários a interesses femininos. (2011, August 18). Folha de São Paulo. Retrieved from http://www1.folha.uol.com. br/multimidia/podcasts/2011/08/961772-movimento-critica-projetos-contrarios-a-interessesfemininos.shtml

Movimento Nacional da Cidadania pela Vida Brasil Sem Aborto. (2011). Café da Manhã com parlamentares pró-vida. Retrieved from http://www.brasilsemaborto.com.br/index. php? action $=$ noticia\&idn noticia $=116 \& \mathrm{cac}$ he $=0.0652514745015651$

Pinho, A. A. (2009). Os debates sobre o aborto na mídia brasileira: Dos enquadramentos midiáticos a construção de uma democracia plural. $E$ -cadernos CES, 135-156. doi:10.4000/eces.233

Pinto, T. F. (2013). Aborto no Brasil atual: Entre o direito e as políticas públicas. Revista Brasileira de Políticas Públicas, 3(1), 13-24. Retrieved from http://www.publicacoesacademicas.uniceub.br/index.php/RBPP/article/view/1951

Pires, T. I. T. (2013). Estado democrático de direito e as liberdades individuais: A legalização do aborto à luz do princípio da autodeterminação. Revista da Faculdade de Direito UFPR, 58, 125-145. doi:10.5380/rfdufpr.v58i0.34868

Rodrigues, E. B. de S. (2012, February). Artigos dos Bispos: Crack, aborto e ideologias. Conferência Nacional dos Bispos do Brasil. Retrieved from http://www.cnbb.org. br/index.php?option $=$ com_content $\& v i e w=$ article \&id=8853: crack-aborto-e-ideologia\&catid $=314 \&$ Itemid $=204$

Rodrigues, F. (2014, June 14). Eleições 2014: Leia a transcrição da entrevista de Eduardo Jorge à Folha e ao UOL. Folha de São Paulo. Retrieved from http://www1.folha.uol.com.br/poder/ poderepolitica/2014/06/1470402-leia-a-transcricao-da-entrevista-de-eduardo-jorge-a-folha-e-ao-uol.shtml

Sagan, C. (1998). Bilhões e bilhões na virada do milênio. São Paulo, SP: Companhia das Letras.

Senado Federal. (2011). Movimento de mulheres critica projetos de lei contrários a interesses femininos. Portal de Noticias. Retrieved from http://www 12.senado.leg.br/noticias/materias/2011/08/18/movimento-de-mulheres-critica-projetos-de-lei-contrarios-a-interesses-femininos 
Senado Federal. (2013). Proposta de novo Código Penal é mais rigorosa com progressões de pena. Retrieved from http://www12.senado.leg.br/ noticias/materias/2013/12/10/proposta-de-novocodigo-penal-e-mais-rigorosa-com-progressoesde-pena

Soares, G. S., Galli, B., \& Viana, A. P. A. L. (2011). Advocacy para o acesso ao aborto legal e seguro: Semelhanças no impacto da ilegalidade na saúde das mulheres e nos serviços de saúde em Pernambuco, Bahia, Paraiba, Mato Grosso do Sul e Rio de Janeiro. Recife, PE: Grupo Curumim.

Taques, P. (2013). Parecer da Comissão Temporária de Estudo da Reforma do Código Penal sobre o Projeto de Lei do Senado ${ }^{\circ} 236$, de 2012, que reforma o Código Penal Brasileiro, e proposições anexadas. Brasília, DF.
Valpassos, C. A. M. (2011). Abortos e histórias sobre eles (Doctoral dissertation, Universidade Federal do Rio de Janeiro, RJ, Brazil).
Recebido: 20/03/2015

$1^{a}$ revisão: $25 / 08 / 2015$ Aceite final: 31/08/2015 